Boise State University

ScholarWorks

$11-2019$

Designing Teacher Preparation Courses: Integrating Mobile Technology, Program Standards, and Course Outcomes

Serena Hicks

Boise State University

Devshikha Bose

Boise State University 
This is an author-produced, peer-reviewed version of this article. The final, definitive version of this document can be found online at TechTrends, published by Springer. Copyright restrictions may apply. doi: 10.1007/s11528-019-00416-z

\title{
Designing Teacher Preparation Courses: Integrating Mobile Technology, Program Standards, and Course Outcomes
}

\author{
Serena Hicks \\ Department of Curriculum, Instruction, \& Foundational Studies \\ College of Education \\ Boise State University \\ serenahicks@boisestate.edu \\ Devshikha Bose \\ Center for Teaching and Learning \\ Boise State University \\ devshikhabose@boisestate.edu
}

\begin{abstract}
This discussion paper demonstrates the need for applying backwards design principles to already-existing course syllabi in order to embed technology alongside pedagogy in teacher preparation programs. The problem is first addressed as a need to integrate technology in one secondary course based on lack of proficiency demonstrated on multiple measures. A design framework that was implemented is then explained, including a step-by-step process for aligning mobile technology applications to course standards and outcomes. Challenges to the process are explored, as well as supports available for duplicating this work in other contexts. The paper concludes with steps the instructor is now taking to encourage and enable other faculty to integrate technology into courses alongside pedagogy training and fieldwork evaluations.
\end{abstract}

Technology integration frameworks have highlighted how teaching is a complex activity which draws upon knowledge of content, pedagogy, and technology (Mishra \& Koehler, 2006). It may not be enough to provide technology training to pre-service teachers with the assumption that the learned skill can then be universally applied while teaching (Zhao \& Bryant, 2006). Early career teachers often experience technology integration barriers like excessive course content, lack of time to create and implement technology integrated lessons, and lack of required software within the school system (Brenner \& Brill, 2016).

Traditional methods of training such as standalone courses and workshops are often insufficient ways to help teachers gain a deep understanding of technology use for pedagogy, and fail to help pre-service teachers integrate technology in their practice (Buss, Foulger, Wetzel, \& Lindsey, 2018; Mishra \& Koehler, 2006; Shih-Hsiung, 2012; Zipke, 2018). Teacher preparation programs must integrate models of curriculum design which allow repeated use and multiple opportunities for preservice teachers to implement technology (Bakir, 2016; Buss et al., 2018). Course design should present an authentic context where teaching candidates learn how to implement the use of technology in their classrooms, and where they experience a model of that design. When teacher educators plan and execute thoughtful technology integration experiences, pre-service teachers gain a more complete idea of how to plan, execute, and assess lessons that have a digital literacy component (Raulston \& Alexiou-Ray, 2018).

While teacher educators' modeling the use of technology may motivate some beginning teachers to integrate technology in their teaching, in many cases the nature of field experience becomes a critical factor influencing their actual practice of technology integration (Admiraal, et al., 2016; Patterson \& Woyshner, 2016; Tondeur, Roblin, Braak, Voogt, \& Prestridge, 2016). Though teaching is increasingly been viewed as a design science, teacher education programs often devote little time to the development of teacher candidates' design expertise, beyond basic lesson planning skills (McKenney, Kali, Markauskaite, \& Voogt, 2015). Hence teacher candidates are often ill prepared to design learning which can truly align content, standards, and technology.

When technology is used to leverage pedagogy, teaching candidates may become well-started beginning teachers with transferable skills that will serve a variety of teaching settings (Bakir, 2016; Buss et al., 2018). The use of mobile devices in and outside the classroom gives students access to information and new ways of learning (Domingo \& 
This is an author-produced, peer-reviewed version of this article. The final, definitive version of this document can be found online at

TechTrends, published by Springer. Copyright restrictions may apply. doi: 10.1007/s11528-019-00416-z

Gargante, 2016; Montrieux, Vanderlinde, Schellens, \& De Marez, 2015). However, theoretical and pedagogical models need to be established that guide teacher educators to design mobile learning experiences for both pre and inservice teachers (Baran, 2014). While technology integration models like the TPACK (Mishra \& Koehler, 2006) have long existed and studies on the development of pre-service teacher TPACK expertise have been conducted (Harris \& Hofer, 2011; Koh \& Divaharan, 2011), there seems to be a lack of studies on actual course designs integrating mobile technology, teacher preparation program standards, and course outcomes.

This discussion paper details how one instructor in a secondary teacher education program in the Northwest United States designed a teacher preparation course through the lens and resources of mobile technology, specifically, with the use of applications that align to programmatic standards and course outcomes. The process was designed to meet the deficit in preparation noted by both completers of the program and Professional Year evaluation scores of candidates in the program, which include technology proficiency.

\section{Understanding the Problem}

Secondary Learning and Instruction is an undergraduate course required for all completers of the secondary program in education at this university, and became the context for course redesign. A new curriculum design was piloted to integrate mobile technology into pedagogy during the last semester of coursework, prior to a culminating field experience in a teacher preparation program. Students enrolled in the course pursue teaching endorsements in content areas such as English, History, Art, Music, World Languages, and other Social Sciences. In general, one section of 25 students is the typical enrollment for this four credit class. Since this is an initial certification program, students enrolled in the course generally have limited teaching experience.

In 2015, completers of this initial preparation program for teacher educators in the Northwest participated in a twoyear study post-graduation. When asked about their preparation to work with technology in the classroom, completers indicated they did not feel prepared after enrollment in an early-program technology course, and that the course was not specific to education (Snow, Dismuke, Wenner, \& Hicks; 2017). Upon searching for studies measuring teacher candidates' perceptions on whether they were prepared to teach with technology, the authors found only one other study where teacher candidates reported feeling unprepared to teach with technology (Haning, 2015).

As noted in earlier studies, teachers need training on how to integrate technology and especially mobile technology in their teaching (Ditzler, Hong, \& Strudler, 2016; Figg \& Jamani, 2013). As recent as 2017, the Teacher Educator Technology Competencies (TETC) were co-created with the goal of defining the competencies (knowledge, skills, and attitudes) that teacher educators need, in order to support teacher candidates who are preparing to teach with technology (Foulger, Graziano, Schmidt-Crawford, \& Slykhuis, 2017). However, these identified competences are relatively new and may not yet be adopted by all teacher educators. Completers of the educator preparation program noted that in order to use technology as more than a production tool in the classroom, they would need practice implementing applications in the classroom setting. They also requested that method teachers in their preparation program integrate technology and focus on the method of teaching with technology rather than the software (Snow et al., 2017). This brought forward the question: In what ways can technology be embedded into already-bulging content and practice outcomes?

During the Fall 2017 semester, data was pulled from midterm observations of preservice teacher candidates across all education programs. Results of observations (see Table 1) indicated that during midterm observations in the field by university liaisons, fewer than half (42\%) the teacher candidates met ISTE Standard 1, and Standards 2, 3, and 4 were met with less than $12 \%$ proficiency. 
This is an author-produced, peer-reviewed version of this article. The final, definitive version of this document can be found online at TechTrends, published by Springer. Copyright restrictions may apply. doi: 10.1007/s11528-019-00416-z

Table 1

Midterm Pre-Service Teacher Field Observations

ISTE Standards data from Taskstream Fall, 2017

\begin{tabular}{|c|c|c|c|}
\hline & $\begin{array}{l}\text { Number of } \\
\text { Responses }\end{array}$ & $\mathrm{Y} / \mathrm{N}$ & $\%$ \\
\hline \multirow{2}{*}{$\begin{array}{l}\text { ISTE Standard 1: Facilitate and } \\
\text { inspire student learning and creativity } \\
\text { (use tech to engage, support, and } \\
\text { inspire learning to promote creative } \\
\text { thinking) }\end{array}$} & 97 & $\mathbf{Y}$ & $42 \%$ \\
\hline & 133 & $\mathrm{~N}$ & $58 \%$ \\
\hline \multirow{2}{*}{$\begin{array}{l}\text { ISTE Standard 2: Design and } \\
\text { develop digital age learning } \\
\text { experiences and assessments (use to } \\
\text { differentiate, personalize, offer } \\
\text { choice, and assess) }\end{array}$} & 18 & $\mathbf{Y}$ & $8 \%$ \\
\hline & 209 & $\mathrm{~N}$ & $92 \%$ \\
\hline \multirow{2}{*}{$\begin{array}{l}\text { ISTE Standard 3: Model digital age } \\
\text { work and learning (use a wide variety } \\
\text { of tech tools to communicate and } \\
\text { collaborate) }\end{array}$} & 25 & $\mathrm{Y}$ & $11 \%$ \\
\hline & 202 & $\mathrm{~N}$ & $89 \%$ \\
\hline \multirow{2}{*}{$\begin{array}{l}\text { ISTE Standard 4: Promote and } \\
\text { model digital citizenship and } \\
\text { responsibility (teach ethical, legal, } \\
\text { safe use) }\end{array}$} & 4 & $\mathrm{Y}$ & $2 \%$ \\
\hline & 220 & $\mathrm{~N}$ & $98 \%$ \\
\hline
\end{tabular}

Note. Y/N: Evaluator indicator in Taskstream based on Formative Assessments 1-4.

Additional reflections from the completer's study and data from Taskstream were the catalyst for designing a framework to impact technology deficits in a secondary education Learning and Instruction course. Taskstream is the cloud-based electronic portfolio platform used at this university. One subject participating in the completer study noted “I just don't feel like I was very prepared technology-wise” and indicated "I can’t remember talking much about technology when I was doing classes." Another completer noted that what she was taught was isolated: "Like this is technology and this is how you use it. Okay, but what does it look like in the classroom?” Completers also noted that they are "figuring it [technology application] out on my own."

\section{An Integrated Models Solution}

The instructor initiated course design by creating a crosswalk template aligning three required standards and course learning objectives: International Society for Technology in Education (ISTE) Standards, Interstate Teacher Assessment and Support Consortium (InTASC) Standards, and course objectives, including the Danielson Framework for Teaching. InTASC Standards outline what a teacher should know and be able to do to prepare K-12 students for college and the workforce, focusing on content, instruction, knowledge of the learner, and professionalism. Course objectives for the design crosswalk also aligned to program outcomes in the College of Education and the Danielson Framework for Teaching, which serves as a pre-service evaluation tool in teacher preparation programs. 
This is an author-produced, peer-reviewed version of this article. The final, definitive version of this document can be found online at TechTrends, published by Springer. Copyright restrictions may apply. doi: 10.1007/s11528-019-00416-z

To create the framework (see Table 2), course objectives were listed first, followed by the supporting Danielson standard. Next, the instructor aligned a general category from the ISTE standards to each course outcome. ISTE Standards prompt teachers to create access to content and learning through technology, set goals for learning, lead and design with technology, and promote goals to develop global digital citizens in the classroom. The ISTE Standards include both general definitions and specific indicators for what each standard looks like in the classroom. For this alignment, the general definitions were used.

Table 2

Framework Aligning InTASC, Danielson Framework, and ISTE Standards with Signature Assignments and Mobile Applications

\begin{tabular}{|c|c|c|c|c|}
\hline $\begin{array}{l}\text { InTASC Standards } \\
\text { and Course } \\
\text { Outcomes }\end{array}$ & $\begin{array}{l}\text { Danielson } \\
\text { Framework for } \\
\text { Teaching }\end{array}$ & ISTE Standard & $\begin{array}{l}\text { Signature } \\
\text { Assignment }\end{array}$ & $\begin{array}{l}\text { Application } \\
\text { Suggestion }\end{array}$ \\
\hline $\begin{array}{l}\text { Planning for } \\
\text { Instruction: The } \\
\text { teacher plans } \\
\text { instruction that } \\
\text { supports every } \\
\text { student in meeting } \\
\text { rigorous learning } \\
\text { goals by drawing } \\
\text { upon knowledge of } \\
\text { content areas, } \\
\text { curriculum, and } \\
\text { cross-disciplinary } \\
\text { skills. }\end{array}$ & $\begin{array}{l}\text { 3c: Engaging } \\
\text { students in learning: } \\
\text { Instructional } \\
\text { materials and } \\
\text { resources }\end{array}$ & $\begin{array}{l}\text { Citizen: Establish a } \\
\text { learning culture that } \\
\text { promotes curiosity } \\
\text { and critical } \\
\text { examination of } \\
\text { online resources and } \\
\text { fosters digital } \\
\text { literacy and media } \\
\text { fluency. }\end{array}$ & Lesson Plan Practice & $\begin{array}{l}\text { Content-based } \\
\text { applications, such } \\
\text { as: } \\
\text { Noet Classics } \\
\text { Research App: a } \\
\text { free and useful } \\
\text { books and resource } \\
\text { app. } \\
\text { Google Arts \& } \\
\text { Culture app: over } \\
\text { 1200 curated } \\
\text { international } \\
\text { museums and } \\
\text { galleries }\end{array}$ \\
\hline $\begin{array}{l}\text { Assessment: The } \\
\text { teacher understands } \\
\text { and uses multiple } \\
\text { methods of } \\
\text { assessment to } \\
\text { engage learners in } \\
\text { their own growth, to } \\
\text { monitor learner } \\
\text { progress, and to } \\
\text { guide the teacher's }\end{array}$ & $\begin{array}{l}\text { 3d: Using } \\
\text { assessment in } \\
\text { instruction: } \\
\text { monitoring student } \\
\text { learning }\end{array}$ & $\begin{array}{l}\text { Analyst: Use } \\
\text { technology to design } \\
\text { and implement a } \\
\text { variety of formative } \\
\text { assessments that } \\
\text { accommodate } \\
\text { learner needs, } \\
\text { provide timely } \\
\text { feedback to } \\
\text { students, and } \\
\text { informs instruction. }\end{array}$ & $\begin{array}{l}\text { Formative } \\
\text { Assessment }\end{array}$ & $\begin{array}{l}\text { Tellagami }{ }^{\circledR} \text { : Create } \\
\text { and share a quick } \\
\text { Gami video } \\
\text { Thinglink: Augment } \\
\text { photos or other } \\
\text { images with text, } \\
\text { audio, links, and } \\
\text { narration }\end{array}$ \\
\hline
\end{tabular}


This is an author-produced, peer-reviewed version of this article. The final, definitive version of this document can be found online at TechTrends, published by Springer. Copyright restrictions may apply. doi: 10.1007/s11528-019-00416-z

\begin{tabular}{|c|c|c|c|c|}
\hline $\begin{array}{l}\text { Content } \\
\text { Knowledge: The } \\
\text { teacher understands } \\
\text { the central concepts, } \\
\text { tools of inquiry, and } \\
\text { structures of the } \\
\text { discipline. }\end{array}$ & $\begin{array}{l}\text { 1e: Designing } \\
\text { Coherent } \\
\text { Instruction: Lesson } \\
\text { and unit structure }\end{array}$ & $\begin{array}{l}\text { Designer: Use } \\
\text { technology to create, } \\
\text { adapt, and } \\
\text { personalize learning } \\
\text { experiences that } \\
\text { foster independent } \\
\text { learning and } \\
\text { accommodate } \\
\text { learner differences } \\
\text { and needs. }\end{array}$ & $\begin{array}{l}\text { Content Concept } \\
\text { Map }\end{array}$ & $\begin{array}{l}\text { Explain Everything: } \\
\text { An interactive } \\
\text { whiteboard and } \\
\text { screencasting app } \\
\text { Inspiration Maps: A } \\
\text { mind mapping, } \\
\text { organizational app } \\
\text { for visual learning } \\
\text { and planning }\end{array}$ \\
\hline
\end{tabular}

\section{Framework for Course Design}

Once the Standards were aligned, the instructor developed signature assignments incorporating standards from all three categories, then a framework was built for learning and teaching, amplified by mobile technology and specific mobile applications. Through this framework, students in the course were exposed to pedagogy and technology simultaneously.

For example, when addressing the InTASC Assessment standard, the teacher created formative assessments for the course reading assignment using the Tellagami ${ }^{\circledR}$ app on class iPads. Tellagami ${ }^{\circledR}$ is a mobile device app which allows users to create and share a quick animated video known as a "Gami Video."Specifically, students were asked to create a Gami video in a context that matched their intended students. Students then prepared and recorded a short summary of the assigned reading using the Tellagami ${ }^{\circledR}$ app. After recording, students shared their recording with three classmates, noting ideas in other Gami videos that they had omitted. Students were asked to revise their Gami video after sharing, to fully represent what they had learned from the reading. The Gami video was then uploaded to Google Drive for the instructor's review. In this way, the process of using the application was embedded in the pedagogy of teaching content. Students practiced the same process they might use with their own students, and the instructor was able to debrief the process of learning alongside the content.

\section{Embedding Technology with Content and Practice Outcomes}

For each course standard and signature assignment, the instructor continued to match a technology application that could be used to leverage pedagogy in the classroom and modeled the process for teacher education students. In most cases, teaching strategies included both analog and digital options, further indicating how technology is selected when it best matches the needs in the classroom, not as an add-on to an already bulging syllabus.

\section{Meeting Student Needs and Accreditation Requirements Through Backwards Design}

Pressure to meet accreditation requirements often impacts course outcomes and design, filling the syllabus with items to "cover" rather than understandings to "uncover" (Wiggins \& McTighe, 2011). Applying backwards design principles to technology integration may increase the likelihood that learners have several opportunities to apply and transfer what they are learning to an authentic teaching context. Aligning required ISTE, InTASC, and Danielson framework standards first clarifies the framework for learning outcomes that are essential to accreditation and university outcomes. Then, evidence of learning through signature assignments, developed through the lens of mobile applications, builds a comprehensive unit design (Wiggins \& McTighe, 2011). Thus, application of the principles of backwards design ensures a "wisely blended" (Wiggins \& McTighe, 2011, p. 7) framework that lends itself to purposeful instruction intended to integrate the process of learning and leading with technology, while also enhancing transfer and pedagogical metacognition.

\section{Prerequisite Knowledge and Partnerships for Framework Implementation}

Implementing an embedded technology framework requires minimal knowledge of technology applications which can be learned through a brief exploration process prior to class or alongside students. In this case, the instructor partnered with the IDEA (Instructional Design and Educational Assessment) Shop, an on-campus faculty support unit of the Center for Teaching and Learning. The instructor participated in the Mobile Learning Scholars (MLS) program, which 
This is an author-produced, peer-reviewed version of this article. The final, definitive version of this document can be found online at TechTrends, published by Springer. Copyright restrictions may apply. doi: 10.1007/s11528-019-00416-z

is a cohort based faculty learning community (FLC) offered by the IDEA Shop. The goal of this FLC is to provide faculty support and shared experiences as they explore and implement ways in which mobile technologies and strategies can be used for teaching and learning. Instructional designers from the IDEA Shop support the FLC through facilitated discussions and mobile technology trainings. Students of faculty who participate in the MLS program are loaned mobile devices for a semester. Currently, the program loans out Apple iPads, however students can use any other mobile device of their choice.

Partnership with the IDEA Shop and participation in the MLS program enabled the instructor to engage in a cohortbased faculty learning community with opportunities for peer learning and feedback exchange. The instructor also received one-on-one consultations with instructional designers regarding the best ways to design a mobile technology enabled curriculum, so as to integrate mobile applications with course learning objectives and pre-service teacher preparation standards.The IDEA shop loaned tablets to the instructor's students for the semester.

\section{A Guide to Using the Framework}

What are the practical implications of this framework? Where can it be used most efficiently towards student learning? A step-by-step process may be useful for teacher educators as well as teachers intending to integrate technology into an already-existing course design with required content components. What follows is a recommended process to begin embedding technology into course design.

1. Review syllabi: Start with a scope and sequence that is already successful, identifying required accreditation, university, department, or course standards. Using existing syllabi, create a table that aligns the standards that are non-negotiable.

2. Identify signature assignments: Where possible, align evidence of student learning to course standards. This process of backwards design begins to collapse and categorize learning, enabling instruction to become layered and condensed.

3. Match standards and signature assignments to potential technology applications: Explore and vet applications that will support the standards and provide students an opportunity to practice the process alongside the content. Not all learning outcomes will find a natural home in technology; resist forcing a fit if there isn't a digital match that is authentic and increases student learning.

4. Leverage technology to improve pedagogy: Oftentimes, instructors are drawn to a digital version of an analog idea (like an app that allows students to draw or annotate), but the enhancements of technology further engage students, which increases time and curiosity with the content. Consider apps that extend student learning and provide strategies that transfer to students' teaching application.

5. Ask for help: Partner with faculty professional development units on campus and information technology department to learn about existing resources to support classrooms with devices, application resources, and tech support. Departments working on Open Educational Resources (OER) may have already vetted applications for ease of use, timely updates, and free options.

6. Keep it simple: Find a solid match between a signature assignment and one or two technology applications and become comfortable modeling its use in one teaching context. Demonstrating pedagogy with technology that is smoothly modeled builds confidence in the process and shares a sustainable strategy for embedding technology with students.

\section{Limitations and Challenges of the Framework}

One challenge to using a framework is finding the best fit for individual instructors and their students. Technology integration frameworks like TPACK have highlighted how teaching is a complex activity which draws upon different kinds of knowledge - knowledge of content, pedagogy, and technology (Mishra \& Koehler, 2006). As expounded in the TPACK framework, "learning technology by design" (p.1034) views learning as best supported when it is situated contextually - when the learning content is an inherent part of the learning context. Therefore, presenting an authentic context where teaching candidates can learn about educational technology is essential if they are to implement the use 
This is an author-produced, peer-reviewed version of this article. The final, definitive version of this document can be found online at TechTrends, published by Springer. Copyright restrictions may apply. doi: 10.1007/s11528-019-00416-z

of technology in their future classrooms. An authentic context comes from an instructor's own design, begins with backwards design from standards, and includes the instructor's unique vision for the course built around knowledge and skills--not merely technology.

In Fall 2018, 22 supervising liaisons from the Teacher Education Liaison Group (TELG) were loaned iPads from The IDEA Shop. The instructor who is also the onsite coordinator for TELG liaisons, introduced this framework to the liaisons during their monthly professional development meetings. The liaisons learned about this framework and reflected through peer discussion on how to integrate mobile applications to candidate supervision and to support Professional Year candidates in the field. Thus, the framework has already been informally introduced to those best positioned to support the transition from classroom to field experience though no formal data was collected about the experiences of the TELG liaisons. From this arises a second challenge to using this framework, i.e. securing the necessary resources for mobile technology use.

In Fall 2018, during the development of this framework, the College of Education at this university requested mobile devices for the Teacher Education Liaison Group (TELG). Due to limited resources, it was not possible to provide mobile devices to both the TELG group and students enrolled in the course. Consequently, collecting data regarding the effectiveness of this design model was delayed in the coursework with students, so that the TELG group might experience mobile technology for education purposes. Therefore, at the time of writing, this framework is still in a formative stage of development and will be tested for reliability in upcoming semesters.

\section{Next Steps}

Data will be collected during pilot implementation of this course design in the following ways:

1. Students enrolled in Secondary Learning \& Instruction will participate in a survey indicating their level of participation and competence with embedded technology during their semester of study. The survey instrument will measure student understanding of each element in the design framework. Students will also be asked to respond to the degree to which they feel prepared to integrate technology into pedagogy in their field experience.

2. Data will be collected from Taskstream during students' first semester in their field experience to determine proficiency in the ISTE standards, as indicated by the Taskstream evaluation.

Data analysis will inform how the framework should be developed further based on these trials. Based on the results from the survey instrument, the framework will be modified to better align with student needs.

As the study moves forward, methods course instructors across teacher preparation programs will be asked to complete a course alignment template which integrates technology application into their course outcomes and signature assignments. Where possible, teachers will implement mobile technology as directed by the template. Surveys will collect data at the end of one semester asking instructors to reflect on the use of the template, including its ease of use, ability to promote alignment, as well as the effectiveness of the applications selected for integration. Instructors will also be asked if the framework supported or created barriers to maintaining the integrity of their course outcomes. Modifications will then be made to the design template, supporting resources, and use of the template based on instructor feedback.

Although currently there is no formal data to report regarding its direct impact in the field for preservice teaching candidates, anecdotal observation-based evidence suggests that the process of integration is impacting teacher education at this university.

\section{Conclusion}

While some instructors may view the use of digital technologies like tablets to be a challenge (Kalonde, 2017; Shraim, \& Crompton, 2015; Souleles, Savva, Watters, \& Annesley, 2017), others may see them as a tool to review their traditional teaching framework (Minicozzi, 2018; Suárez-Guerrero, Lloret-Catalá, \& Mengual-Andrés, 2016). Use of digital tools like tablets enhance meaningful learning in various disciplines of higher education. Collaborative language learning (Jiménez, García, \& Íñiguez, 2016), class interaction, formative assessment (Wijtmans, van Rens, \& van Muijlwijk-Koezen, 2014), and higher order math learning (Volk, Cotič, Zajc, \& Istenic Starcic, 2017), can 
This is an author-produced, peer-reviewed version of this article. The final, definitive version of this document can be found online at TechTrends, published by Springer. Copyright restrictions may apply. doi: 10.1007/s11528-019-00416-z

improve as a result of including mobile learning devices in teaching and learning. Teacher education instructors in a variety of content areas can leverage technology in their courses for enhanced learning and motivation (Hui-Chun \& Shwu-Ching, 2017). Beginning the process with an embedded technology framework invites instructors to begin with their own materials and slowly layer applications that align to already-determined outcomes and signature assignments, simplifying the process while enhancing learning.

\section{References}

Admiraal, W., Vugt, F.V., Kranenburg, F., Koster, B., Smit, B., Weijers, S., \& Lockhorst, D. (2017). Preparing preservice teachers to integrate technology into K-12 instruction: evaluation of a technology-infused approach, Technology. Pedagogy and Education, 26(1), 105-120, DOI: 10.1080/1475939X.2016.1163283

Bakir, N. (2016). Technology and Teacher Education: A brief glimpse of the research and practice that have shaped the field. Tech Trends, 60, 21-19. DOI: 10.1007/s11528-015-0013-4.

Baran, E. (2014). A review of research on mobile learning in teacher education. Journal of Educational Technology \& Society, 17(4), 17-32.

Brenner, A.M., \& Brill, J.M. (2016). Investigating practices in teacher education that promote and inhibit technology integration transfer in early career teachers. TechTrends, 60(2), 136-144.

Buss, R.R., Foulger, T.S., Wetzel, K., \& Lindsey, L (2018). Preparing teachers to integrate technology into K-12 Instruction II: Examining the effects of technology-infused methods courses and student teaching. Journal of Digital Learning in Teacher Education, 34(3), 134-150, DOI: 10.1080/21532974.2018.1437852

Ditzler, C., Hong, E., \& Strudler, N. (2016). How tablets are utilized in the classroom. Journal of Research of Technology in Education, 48(3), 181-193, DOI: 10.1080/15391523.2016.1172444

Domingo, M.G., \& Gargante, A.B. (2016). Exploring the use of educational technology in primary education: Teachers' perception of mobile technology learning impacts and applications' use in the classroom. Computers in Human Behavior, 56, 21-28.

Figg, C., \& Jamani, K.J.(2013). Transforming classroom practice: Technology professional development that works! Teaching \& Learning,8(1), 87-98. DOI: HTTPS://DOI.ORG/10.26522/TL.V8I1.431

Foulger, T.S., Graziano, K.J., Schmidt-Crawford, D. \& Slykhuis, D.A. (2017). Teacher educator technology competencies. Journal of Technology and Teacher Education, 25(4), 413-448. Waynesville, NC USA: Society for Information Technology \& Teacher Education. Retrieved July 15, 2019 from https://www.learntechlib.org/primary/p/181966/.

Haning, M. (2015). Are they ready to teach with technology? An investigation of technology instruction in Music teacher education programs. Journal of Music Teacher Education, 25(3), 78-90.

Harris, J.B., \& Hofer, M.J. (2011). Technological Pedagogical Content Knowledge (TPACK) in Action: A descriptive study of secondary teachers' curriculum-based, technology-related instructional planning. Journal of Research on Technology in Education, 43(3), 211-229, DOI: 10.1080/15391523.2011.10782570

Hui-Chun, H., \& Shelley Shwu-Ching, Y. (2017). Applying multi-touch technology to facilitate the learning of art appreciation: from the view of motivation and annotation. Interactive Learning Environments, 25(6), 733748. doi:10.1080/10494820.2016.1172490

Jiménez, C. S., García, S. R., \& Íñiguez, F. M. (2016). Integración de tabletas digitales como herramienta mediadora en procesos de aprendizaje. Apertura: Revista De Innovación Educativa, 8(2), 70-83. doi:10.18381/Ap.v8n2.880

Kalonde, G. (2017). Technology use in rural schools: A study of a rural high school trying to use iPads in the classroom. Rural Educator, 38(3), 27-38.

Koh, J.H.L. \& Divaharan, S. (2011). Developing pre-service teachers' technology integration expertise through the TPACK-developing instructional model. Journal of Educational Computing Research, 44(1), 35-58.

McKenney, S., Kali, Y., Markauskaite, L., \& Voogt, J. (2015). Teacher design knowledge for technology enhanced learning: An ecological framework for investigating assets and needs. Instructional Science: An International Journal of the Learning Sciences, 43(2), 181-202

Minicozzi, L. L. (2018). iPads and pre-service teaching: exploring the use of iPads in k-2 classrooms. International Journal of Information \& Learning Technology, 35(3), 160-180. https://doi.org/10.1108/IJILT-05-20170032

Mishra, P., \& Koehler, M. J. (2006). Technological pedagogical content knowledge: A framework for teacher knowledge. Teachers College Record, 108(6), 1017-1054. doi: 10.1111/j.1467-9620.2006.00684.x. 
This is an author-produced, peer-reviewed version of this article. The final, definitive version of this document can be found online at TechTrends, published by Springer. Copyright restrictions may apply. doi: 10.1007/s11528-019-00416-z

Montrieux, H., Vanderlinde, R., Schellens, T., \& De Marez, L. (2015). Teaching and learning with mobile technology: A qualitative explorative study about the introduction of tablet devices in secondary education. PLOS ONE 10(12): e0144008. doi:10.1371/journal.pone.0144008

Patterson, T., \& Woyshner, C. (2016). History in other contexts: Pre-service history teachers' field placements at cultural institutions. History Teacher, 50(1), 9-31. Retrieved from http://search.ebscohost.com/login.aspx?direct=true\&db=khh\&AN=120972806\&site=ehost-live

Raulston, C. G., \& Alexiou-Ray, J. (2018). Preparing more technology- literate preservice teachers: A changing paradigm in higher education. Delta Kappa Gamma Bulletin, 84(5), 9-13. Retrieved from http://search.ebscohost.com/login.aspx?direct=true\&db=aph\&AN=135612911\&site=ehost-live

Shih-Hsiung, L. (2012). A Multivariate model of factors influencing technology use by preservice teachers during practice teaching. Journal of Educational Technology \& Society, 15(4), 137-149.

Shraim, K., \& Crompton, H. (2015). Perceptions of using smart mobile devices in higher education teaching: A case study from palestine. Contemporary Educational Technology, 6(4), 301-318. Retrieved from http://search.ebscohost.com/login.aspx?direct=true\&db=eric\&AN=EJ1105758\&site=ehost-live

Snow, J.L., Dismuke, S., Wenner, J., Hicks, S. (in press). Facing practice as teacher educators: A self-study of program graduates. In Preparing the Next Generation of Teacher Educators. Advances in Teacher Education Book Series.

Souleles, N., Savva, S., Watters, H., \& Annesley, A. (2017). Perceptions of art and design faculty on the instructional value of iPads. Technology, Pedagogy and Education, 26(2), 211-223. Retrieved from http://search.ebscohost.com/login.aspx?direct=true\&db=eric\&AN=EJ1135383\&site=ehost-live

Suárez-Guerrero, C., Lloret-Catalá, C., \& Mengual-Andrés, S. (2016). Teachers' perceptions of the digital transformation of the classroom through the use of tablets: A study in Spain. Comunicar, 24(49), 81-89. doi:10.3916/C49-2016-08

Tondeur, J., Roblin, N.P., Braak, J.V., Voogt, J., \& Prestridge, S. (2016). Preparing beginning teachers for technology integration in education: Ready for take-off? Technology, Pedagogy, and Education, 26(2), 157-177.

Volk, M., Cotič, M., Zajc, M., \& Istenic Starcic, A. (2017). Tablet-based cross-curricular maths vs. traditional maths classroom practice for higher-order learning outcomes. Computers \& Education, 1141-23. doi:10.1016/j.compedu.2017.06.004

Wiggins, G. \& McTighe, J. (2011). The understanding by design guide to creating high-quality units. Alexandria, VA: ASCD.

Wijtmans, M., van Rens, L., \& van Muijlwijk-Koezen, J. E. (2014). Activating students' interest and participation in lectures and practical courses using their electronic devices. Journal of Chemical Education, 91(11), 18301837. doi:10.1021/ed500148r

Zhao, Y., \& Bryant, F.L. (2006). Can teacher technology integration training alone lead to high levels of technology integration? A qualitative look at teachers' technology integration after state mandated technology training. Electronic Journal for the Integration of Technology in Education, 5, 53-62.

Zipke, M. (2018). Preparing teachers to teach with technology: Examining the effectiveness of a course in educational technology. The New Educator, 14(4), 342-362.

https://www.iste.org/standards/for-educators

\section{Appendix}

\section{Definition of terms:}

Lesson Plan Practice: Students will be able to plan a series of three lesson plans aligned to their content area, using content-based applications as part of the input options of the lesson. Each lesson plan includes high impact teaching strategies.

Formative Assessment: Students will be able design formative assessments aligned to learning targets. Authentic assessments include student choice and multi-modal evidence of learning.

Content Concept Map: Students will be able to design a concept map demonstrating understanding of the connections between content standards. 